\title{
Analisis Kimia dan Kualitas Air Hujan di Kota Palu Sebagai Penyebab Terjadinya Hujan Asam
}

\author{
Solih Alfiandy ${ }^{*}$, Donaldi Sukma Permana ${ }^{1}$, Muharam Syam Nugraha ${ }^{2}$, Isna Jutika Aulia Putri ${ }^{3}$ \\ ${ }^{S}$ tasiun Pemantau Atmosfer Global (GAW), Badan Meteorologi Klimatologi dan Geofisika, Palu, \\ Sulawesi Tengah 94231, Indonesia \\ 2Laboratorium Kualitas Udara, Badan Meteorologi Klimatologi dan Geofisika, DKI Jakarta 10720, \\ Indonesia \\ 3Stasiun Meteorologi Mutiara Sis Aljufri, Badan Meteorologi Klimatologi dan Geofisika, Palu, Sulawesi \\ Tengah 94231, Indonesia
}

Corresponding author:

Solih Alfiandy

solih.alfiandy@bmkg.go.id

Received: January 2021

Accepted: March 2021

Published: March 2021

(c) Solih Alfiandy et al. This is an open-access article distributed under the terms of the Creative Commons Attribution License, which permits unrestricted use distribution, and reproduction in any medium, provided the original author and source are credited.

\begin{abstract}
Acidic compounds such as sulfur dioxide $\left(\mathrm{SO}_{2}\right)$ and nitrogen oxides $\left(\mathrm{NO}_{\mathrm{x}}\right)$, which are generally emitted into the atmosphere by human activities from burning fossil fuels, motor vehicles and industry, react with water and oxygen to produce acidic rain that falls to the earth's surface. This study aims to investigate the quality of rainwater chemical compounds at the Mutiara Palu Meteorological Station using 282 samples derived from the BMKG Air Quality Database during February 1993 - January 2020. The method used are descriptive analysis and correlation analysis to determine the relationship between chemical compound reactions that occur in the rainwater in Palu City. The results showed that the chemical compounds in rainwater in Palu City were dominated by strong acid compounds in the form of $\mathrm{Cl}^{-}, \mathrm{SO}_{4}{ }^{2-}$, and $\mathrm{NO}_{3}$ - compounds with a percentage of $63 \%$ and the most dominant quality was in the acidic rain category with a $\mathrm{pH}$ value below 5.6 , as much as $55.7 \%$. Chemical compounds contained in rainwater in Palu City are mineral compounds that originated from natural form of minerals, particularly from sea salt. The relationship between chemical compounds contained in rainwater has varied values and is in the low to moderate category. In general, the results indicate that the quality of rainwater in Palu City is low and not recommended for health and the environment.
\end{abstract}

Keywords: rainwater chemistry, rainwater quality, acid rain in Palu City

\section{Pendahuluan}

Informasi tentang hujan asam sangat penting bagi kehidupan mahluk hidup seperti kesehatan tubuh manusia, kesuburan lingkungan, dan sebagai langkah antisipasi untuk pencegahan kerusakan pada bangunan serta yang berhubungan dengan kerusakan lainnya. Air hujan merupakan air yang berasal dari proses penguapan, kemudian mengalami kondensasi dan turun ke permukaan bumi sebagai hujan ${ }^{[1]}$. Laut di sekitar wilayah pulau Sulawesi memiliki peran dalam proses penguapan ${ }^{[2]}$ yang terjadi di wilayah Kota Palu karena letak geografi dan topografinya yang unik[3]. Sebelum sampai di permukaan bumi, air hujan mengalami proses percampuran dengan partikulat debu dan gasgas rumah kaca yang ada di atmosfer dari aktivitas manusia dan aktivitas alam ${ }^{[4,5]}$. Selain partikulat debu dan gas rumah kaca, air hujan 
yang turun sebagai hasil dari proses penguapan juga membawa zat-zat dan senyawa yang berasal dari lautan[6,7], karena kita ketahui bahwa penguapan terbesar terjadi di laut dibandingkan daratan.

Akibat dari proses percampuran antara air hujan dengan partikulat debu dan gas rumah kaca, hujan yang sampai di permukaan bumi akan menjadi asam atau memiliki nilai derajat keasaman $(\mathrm{pH})$ yang rendah bahkan sangat rendah yakni <5.6, hasil dari proses tersebut dinamakan sebagai hujan asam ${ }^{[8]}$. Hujan asam biasa terjadi pada daerah-daerah yang padat penduduk dan banyaknya aktivitas manusia dalam penggunaan kendaraan bermotor, terdapat pabrik dan dekat dengan gunung berapi yang masih aktif. Curah hujan dan partikulat debu memiliki nilai korelasi negatif yang cukup karena partikulat debu akan larut bersamaan dengan air hujan yang jatuh ke permukaan ${ }^{[9]}$.

Hujan asam memiliki karakteristik khusus yang menjadi ciri khas sekaligus perbedaan dengan jenis hujan lainnya seperti hujan es, hujan salju dan hujan rintik-rintik. Hujan asam merupakan hujan yang memiliki tingkat keasaman $(\mathrm{pH})$ dibawah 5.6[1]. Penyebab terjadinya hujan asam karena adanya pertemuan gas hasil proses pembakaran bahan bakar dari kendaraan bermotor maupun aktivitas alam berupa karbondioksida $\left(\mathrm{CO}_{2}\right)$ dan karbon monoksida (CO) yang bertemu dengan uap air $\left(\mathrm{H}_{2} \mathrm{O}\right)$ yang telah tercampur dengan senyawa lain hasil penguapan hingga membentuk asam karbonat $\left(\mathrm{H}_{2} \mathrm{CO}_{3}\right)$, hasil dari pertemuan gas tersebut termasuk ke dalam kategori asam lemah ${ }^{[10,11]}$. Kemudian gas hasil pembakaran atau pemanasan dari belerang berupa hidrogen sulfida $\left(\mathrm{H}_{2} \mathrm{~S}\right)$ dan sulfur oksida $\left(\mathrm{SO}_{2}\right)$ yang bertemu dengan uap air $\left(\mathrm{H}_{2} \mathrm{O}\right)$ akan membentuk asam sulfat $\left(\mathrm{H}_{2} \mathrm{SO}_{4}\right)$, hasil dari pertemuan gas tersebut termasuk ke dalam kategori asam kuat $^{[4]}$

Proses hujan asam dapat terjadi akibat adanya aktivitas manusia dan aktivitas alam yang menimbulkan munculnya gas-gas penyebab hujan asam seperti karbondioksida, karbon monoksida, sulfur dioksida dan hidrogen [12].
Gas-gas tersebut akan mengendap bahkan larut bersamaan uap air yang telah menjadi embun maupun turun sebagai hujan. Gas-gas hasil pembakaran akan terbawa oleh angin menuju tempat yang jauh dari sumbernya dan semakin ke atas. Ketika telah sampai di atas (atmosfer), gas akan bercampur dengan uap air (awan) dan uap air tersebut sewaktu-waktu akan jenuh hingga akhirnya melepaskan massa yang dibawanya menjadi butiran-butiran es (cairan) ${ }^{[13]}$. Hasil kombinasi percampuran antara uap air yang mengandung senyawa-senyawa anorganik dan gas-gas yang memiliki sifat asam-basa lemah maupun asam-basa kuat itulah yang akan menghasilkan hujan asam.

Dampak yang timbulkan dari hujan asam yakni (1) mengotori dan merusak bangunan, (2) merusak material, (3) merusak tumbuhan dan tanah, (4) merusak ekosistem air, dan (5) kesehatan manusia. Berdasarkan latarbelakang dan dampak yang ditimbulkan dari hujan asam, maka tujuan dari penelitian ini adalah untuk mengetahui sifat kimia dan kualitas $(\mathrm{pH})$ pada air hujan di Kota Palu. Manfaat dari penelitian ini adalah sebagai informasi untuk mengetahui potensi kualitas air hujan yang akan terjadi di Kota Palu pada periode mendatang.

\section{Metode Penelitian}

\section{Data}

Data kimia air hujan yang digunakan dalam kajian penelitian ini berasal dari Database Kualitas Udara (DBKU) Badan Meteorologi Klimatologi dan Geofisika (BMKG) yang merupakan pengukuran periode dua mingguan dari tahun 1993 bulan Februari minggu ke dua hingga tahun 2020 bulan Januari minggu ke dua dengan total data sebanyak 282 sampel. Pengambilan sampel dilakukan menggunakan metode Wet Deposition dan Wet $\mathcal{E}$ Dry Deposition dengan alat Automatic Rain Water Sampler (ARWS). Data yang digunakan dalam analisa kualitas dan sifat kimia air hujan berupa $\mathrm{KT}, \mathrm{Cl}$, $\mathrm{SO}_{4}, \mathrm{NO}, \mathrm{Ca}, \mathrm{Na}, \mathrm{K}, \mathrm{Mg}, \mathrm{NH}_{4}, \mathrm{pH}$, serta $\mathrm{DHL}$ yang didapatkan dari hasil perhitungan menggunakan metode ion kromatografi, pengukur $\mathrm{pH}$ (Kalkulasi Keseimbangan Ion) dan konduktivitimeter. Terdapat data bolong 
periode 2005 - 2013 dikarenakan alat rusak dan belum ada pembaharuan alat hingga tahun 2013, data tersedia kembali sejak tahun 2014.

\section{Metode}

Metode yang digunakan dalam penelitian ini berupa analisis deskriptif, perhitungan prosentase, analisis korelasi. Analisis deskriptif digunakan untuk membaca pola nilai $\mathrm{pH}$ dan kimia air hujan lainnya. Analisis korelasi digunakan untuk mengetahui hubungan dari masing-masing parameter kimia yang telah diketahui.

Perhitungan prosentase dilakukan untuk mengetahui seberapa banyak nilai asam dan basa kuat serta lemah dari air hujan di Kota Palu dengan cara sebagai berikut:

$$
X=\frac{A}{H} \times 100
$$

Keterangan: $\mathrm{X}=$ nilai prosentase

$$
\begin{aligned}
& A=\text { jumlah nilai data } \\
& \mathrm{H}=\text { Total data }
\end{aligned}
$$

Analisis korelasi digunakan untuk mengetahui seberapa kuat hubungan reaksi antar unsur kimia air hujan. Korelasi yang digunakan adalah korelasi pearson (r). Nilai koefisien korelasi berada antara 1 dan $-1(-1 \leq r \leq 1)$, dimana angka +1 dan -1 menunjukan hubungan yang erat antara kedua variabel, sedangkan angka 0 menunjukan tidak ada hubungan antara kedua variabel terkait. Secara sederhana korelasi pearson dapat dirumuskan sebagai berikut ${ }^{[14]}$.

$$
r_{x y}=\frac{n \Sigma X Y-\Sigma X \Sigma Y}{\sqrt{n \Sigma X^{2}-(\Sigma X)^{2}} \sqrt{n \Sigma Y^{2}(\Sigma Y)^{2}}}
$$

Keterangan: $\quad r_{x y}=$ Koefisien korelasi $X=$ Variabel tidak terikat $X$ $Y=$ Variabel terikat $Y$ $n$ = Jumlah data

Untuk mengetahui uji dari hasil korelasi antar variable-variabel digunakan uji $p$ - value atau biasa disebut dengan uji sinifikan. Jika nilai $p-$ value 0.05 atau memiliki tingkat kepercayaan sebesar 95\%, maka nilai hasil korelasi signifikan dan sebaliknya jika lebih dari 0.05 maka nilai hasil korelasi kedua variabel tidak signifikan ${ }^{[14]}$.

\section{Hasil dan Diskusi}

\section{Derajat keasaman (pH)}

Gambar 1 menunjukkan bahwa nilai derajat keasaman $(\mathrm{pH})$ air hujan di wilayah pengamatan Stasiun Meteorologi Palu memiliki variasi dengan rentang nilai 3.5 - 7. Kategori sifat kimia hujan merujuk pada kategori yang telah ditentukan oleh Badan Meteorologi Klimatologi dan Geofisika (BMKG) (Tabel 1). Variasi nilai derajat keasaman air hujan bergantung pada kadar zat kimia yang terlarut.

Banyaknya nilai derajat keasaman $(\mathrm{pH}) \quad>7$ dengan kategori hujan basa memiliki persentase sebesar $7.4 \%$ dari total data. Nilai derajat keasaman 6.1 - 7 dengan kategori sangat baik atau cenderung netral memiliki persentase sebesar $16 \%$ dari total data.

Tabel 1. Kategori nilai $\mathrm{pH}$ air hujan

\begin{tabular}{cl}
\hline $\mathrm{pH}$ & pH Basa \\
$>7$ & Air hujan sangat baik, cenderung netral seperti air permukaan \\
$6.1-7$ & pH air hujan ideal \\
$5.6-6$ & Hujan asam \\
$4.1-5.5$ & Hujan asam (tinggi) \\
$3-4$ & Hujan asam (ekstrem) \\
\hline
\end{tabular}

Sumber: BMKG 


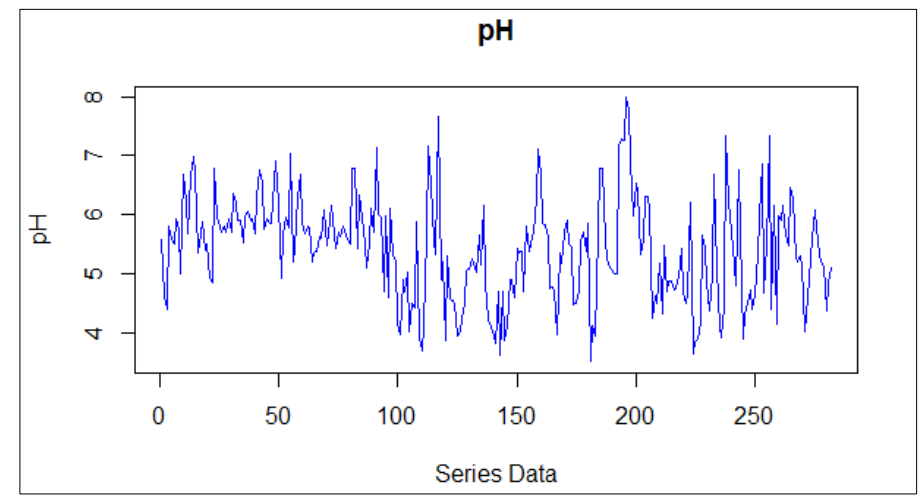

Gambar 1. Deret waktu nilai derajat keasaman (pH) Stasiun Meteorologi Palu periode 1993 - 2020.

Nilai derajat keasaman $5.6-6$ dengan kategori hujan ideal memiliki persentase sebesar $28 \%$ dari total data. Nilai derajat keasaman $4.1-5$ dengan kategori hujan asam memiliki persentase sebesar $44.7 \%$ dari total data. Kemudian untuk nilai derajat keasaman $3-4$ dengan kategori hujan asam tinggi memiliki persentase sebesar $7.1 \%$ dari total data. Persentase total nilai derajat keasaman $(\mathrm{pH})$ kurang dari 5.6 sebesar $55.7 \%$ dan lebih besar sama dengan 5.6 sebesar $44.3 \%$. Dapat dikatakan bahwa curah hujan di Stasiun Meteorologi Mutiara Palu sepanjang tahun sesuai ketersediaan data dominan memiliki kategori hujan asam. Menurut [15] biasanya hujan memiliki nilai $\mathrm{pH}$ 6, apabila kadar nilai $\mathrm{pH}$ dibawah 5.6 maka dianggap sebagai hujan asam. Menurut [16] hujan asam sangat merugikan karena dapat merusak tanaman dan kesuburan tanah yang berhujung pada kerusakan lingkungan.

Rendahnya nilai derajat keasaman dikarenakan lokasi pengamatan air hujan berada di area wilayah Bandar Udara Mutiara Sis Al-Jufri Palu, tepatnya di sebelah landasan pacu. Selain itu, lokasi pengamatan berada di tengah kota Palu dan dekat dengan lautan. Hal tersebut dapat mempengaruhi kualitas air hujan karena banyak tercampur zat-zat kimia hasil pembakaran bahan bakar kendaraan bermotor dan zat-zat kimia hasil alam yang berada di lautan serta sumber lainnya dari alam, penelitian yang dilakukan oleh ${ }^{[17]}$ menyebutkan bahwa penyumbang terbesar terjadinya hujan asam adalah gas hasil pembakaran bahan bakar seperti solar, bensin dan minyak tanah. Menurut ${ }^{[16]}$ apabila asam sulfat dan asam sulfit turun ke bumi bersama-sama dengan jatuhnya hujan, maka terjadilah yang dikenal sebagai hujan asam.

\section{Persentase senyawa kimia air hujan di Kota Palu}

Tabel 2 menunjukkan persentase senyawa kimia penyebab rendahnya nilai derajat keasaman $(<5.6)$ yang terkandung pada air hujan di Kota Palu dalam kategori asam dan basa kuat serta lemah.

Tabel 2. Persentase senyawa kimia yang terkandung pada air hujan di Kota Palu

\begin{tabular}{|c|c|c|c|c|c|c|c|}
\hline \multicolumn{3}{|c|}{ Asam kuat (\%) } & \multicolumn{3}{|c|}{ Basa kuat (\%) } & \multicolumn{2}{|c|}{ Basa lemah (\%) } \\
\hline $\mathrm{Cl}^{-}$ & $\mathrm{SO}_{4}{ }^{2-}$ & $\mathrm{NO}_{3}^{-}$ & $\mathrm{Ca}^{2+}$ & $\mathrm{Na}^{+}$ & $\mathrm{K}^{+}$ & $\mathrm{Mg}^{2+}$ & $\mathrm{NH}_{4}{ }^{+}$ \\
\hline 14 & 12 & 37 & 14 & 6 & 7 & 2 & 8 \\
\hline Jumlah & $+\mathrm{SO}_{4}{ }^{2}$ & $3^{-}=63 \%$ & Jumlah & $+\mathrm{Na}^{+}$ & $27 \%$ & Jumlah (\% & $\mathrm{H}_{4^{+}}=10 \%$ \\
\hline
\end{tabular}


Persentase terbesar yaitu terjadi pada asam kuat dengan jumlah persentase sebesar $63 \%$. Asam kuat merupakan asam yang bila dilarutkan dengan air dapat terionisasi sepenuhnya dan menghasilkan banyak ion $\mathrm{H}^{+}$, asam kuat pada sebuah larutan akan membuat $\mathrm{pH}$ menjadi rendah yakni dibawah 5 . Kemudian persentase berikutnya adalah basa kuat, basa kuat merupakan asam yang bila dilarutkan sepenuhnya dapat terionisasi dan menghasilkan banyak ion hidroksida atau $\mathrm{OH}^{-}$. Persentase berikutnya yaitu basa lemah. Jika basa lemah dilarutkan, maka hanya sebagian ion saja yang dapat terionisasi dan hanya menghasilkan sedikit ion $\mathrm{OH}^{-}$, serta nilai $\mathrm{pH}$ yang terkandung akan mengalami sedikit kenaikan. Selanjutnya adalah reaksi antara asam dan basa yang disebut dengan reaksi penetralan, akan tetapi hasil reaksi tidak selalu bersifat netral. Sifat asam basa dari larutan air hujan bergantung pada kekuatan asam dan basa penyusunnya. Larutan yang berasal dari asam kuat dan basa kuat bersifat netral, contohnya $\mathrm{NaCl}$ dan $\mathrm{KNO}_{3}$. Larutan yang berasal dari asam kuat dan basa lemah bersifat asam, contohnya adalah $\mathrm{NH}_{4} \mathrm{Cl}$. Senyawa-senyawa yang terkandung dalam air hujan tersebut yang dapat menjadikan hujan yang terjadi di wilayah Kota Palu bersifat sebagai hujan asam atau hujan dengan kategori normal.

\section{Scatterplot $\mathbf{p H}$, DHL dan Ion}

Rentang jumlah ion yang terdapat pada air hujan di Stasiun Meteorologi Mutiara Palu yaitu $\mathrm{Ca}^{2+}$ dengan rentang nilai $0-49.77 \mathrm{mg} / \mathrm{L}, \mathrm{Mg}^{2+}$ dengan rentang nilai $0-3.636 \mathrm{mg} / \mathrm{L}, \mathrm{Na}^{+}$dengan rentang nilai $0-13.27 \mathrm{mg} / \mathrm{L}, \mathrm{K}^{+}$dengan rentang nilai $0-24 \mathrm{mg} / \mathrm{L}, \mathrm{NH}_{4}{ }^{+}$dengan rentang nilai $0-$ $30.3 \mathrm{mg} / \mathrm{L}, \mathrm{Cl}^{-}$dengan rentang nilai $0-30.94$ $\mathrm{mg} / \mathrm{L}, \mathrm{SO}_{4}{ }^{2-}$ dengan rentang nilai $0-26.73 \mathrm{mg} / \mathrm{L}$, $\mathrm{NO}_{3}{ }^{-}$dengan rentang nilai $0-115.6 \mathrm{mg} / \mathrm{L}$ dan memiliki nilai daya hantar listrik (DHL) yang berada di rentang $0.34-788.8 \mathrm{mho} / \mathrm{cm}$. Analisis menunjukkan bahwa unsur kimia yang terkandung pada air hujan tersebut merupakan senyawa anorganik yang berasal dari alam berbentuk mineral.

Gambar 2a menunjukkan penyebaran antara derajat keasaman $(\mathrm{pH})$ dan nilai daya hantar listrik (DHL), penyebaran DHL terhadap $\mathrm{pH}$ terbanyak berada pada saat nilai $\mathrm{pH}<6$. Terdapat penyebaran DHL pada saat nilai $\mathrm{pH}>6$ dikarenakan terdapat kandungan ion positif dengan nilai yang tinggi dalam air hujan tersebut sehingga nilai DHL menjadi tinggi. Gambar 2b-2i menunjukkan penyebaran unsur kimia terhadap DHL, penyebaran unsur-unsur terbanyak berada pada saat nilai DHL berada di angka 0 - $200 \mathrm{mho} / \mathrm{cm}$ dan terdapat juga nilai unsur-unsur kimia dengan nilai yang rendah serta tinggi pada saat nilai DHL $>200 \mathrm{mho} / \mathrm{cm}$. Semakin besar jumlah padatan terlarut di dalam larutan air, maka kemungkinan jumlah ion di dalam larutan juga akan semakin besar, sehingga nilai konduktivitas listrik juga akan semakin besar ${ }^{[18]}$.

\section{Reaksi Kimia}

Tabel 3 merupakan reaksi kimia yang mungkin dapat terjadi pada sampel air hujan. Dari hasil analisis reaksi kimia yang mungkin terjadi menunjukkan bahwa air hujan yang diamati di Stasiun Meteorologi Mutiara Sis Al - Jufri Palu banyak mengandung garam yang berasal dari lautan. Reaksi kimia ini dijelaskan sebagai pengetahun tentang asal atau sumber penyebab terjadinya air hujan di Kota Palu menjadi asam.

\section{Korelasi pearson antar kimia pada air hujan}

Dapat dilihat pada Tabel 4 dimana korelasi antara derajat keasaman $(\mathrm{pH})$ dan daya hantar listrik (DHL) memiliki nilai korelasi positif yang cukup rendah karena didominasi oleh banyaknya ion positif sehingga rata-rata nilai derajat keasaman $(\mathrm{pH})$ rendah atau didominasi oleh senyawa asam kuat. Rata-rata nilai nilai derajat keasaman $(\mathrm{pH})$ berdasarkan banyaknya jumlah data yaitu 5.43 dan rata-rata nilai daya hantar listrik (DHL) sebesar $28.7 \mathrm{mho} / \mathrm{cm}$. Kemudian korelasi antara daya hantar listrik terhadap elektrolit (Tabel 4) yang terdapat pada air hujan di kota Palu memiliki pengaruh positif yang tinggi yakni $0.303-0.807$. Tingginya nilai korelasi antara daya hantar listrik terhadap ionion dari jenis elektrolit memiliki makna bahwa semakin besar jumlah ion pada air hujan, maka semakin tinggi nilai konduktivitasnya. 

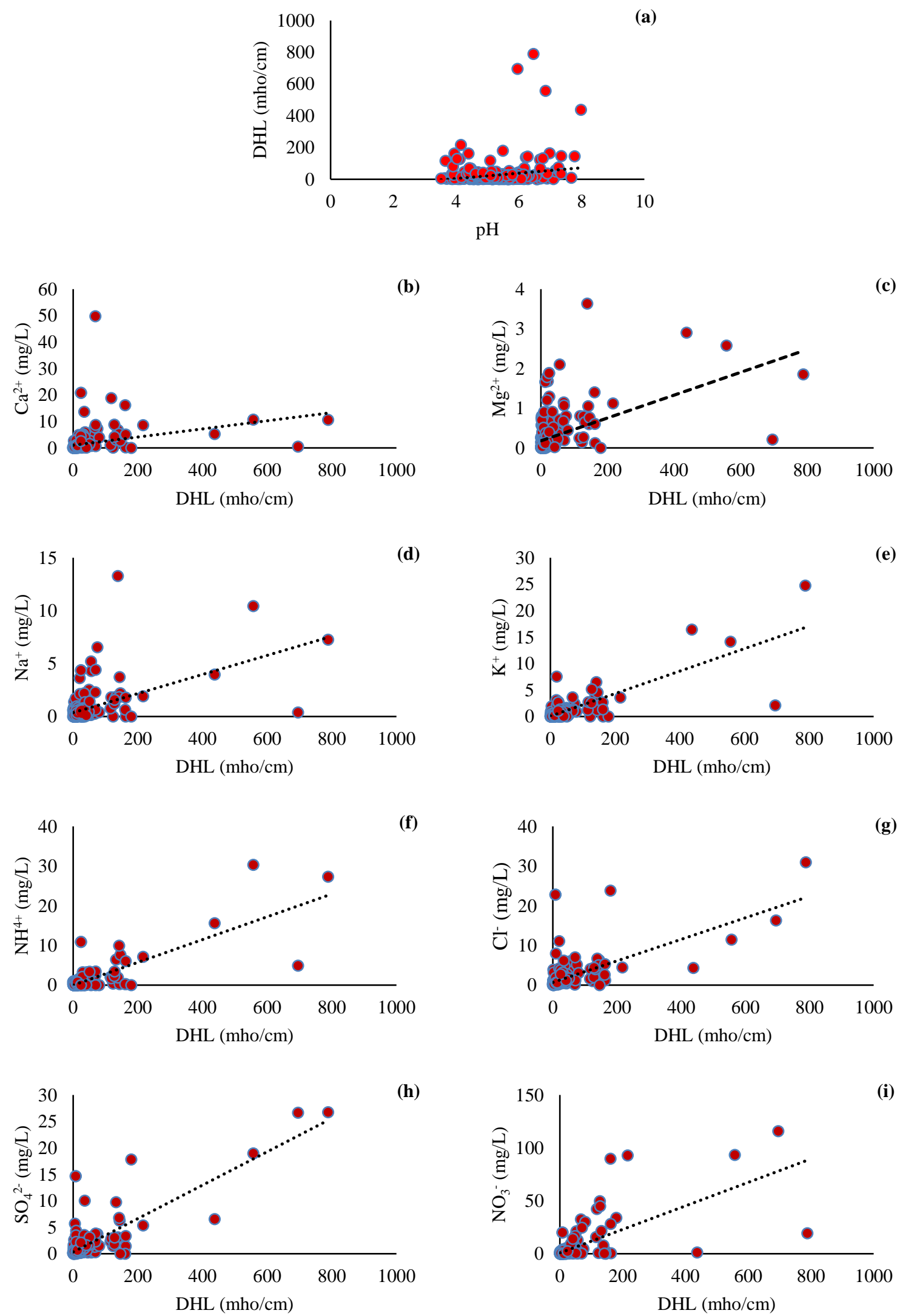

Gambar 2. Scatterplot (a) pH dan DHL; (b) DHL dan Ca; (c) DHL dan Mg; (d) DHL dan Na; (e) DHL dan K; (f) DHL dan $\mathrm{NH}_{4}$; (g) DHL dan $\mathrm{Cl}$; (h) DHL dan $\mathrm{SO}_{4}$; (i) DHL dan $\mathrm{NO}_{3}$. 
Tabel 3. Kemungkinan reaksi senyawa kimia yang terjadi pada air hujan di Stasiun Meteorologi Mutiara Sis Al-Jufri Palu

\begin{tabular}{|c|c|c|}
\hline \multicolumn{3}{|c|}{ Reaksi Kimia } \\
\hline Kemungkinan reaksi yang terjadi & Reaksi & Jenis \\
\hline $\mathrm{Ca}^{2+}+\mathrm{Cl}^{-}$ & $\mathrm{CaCl}_{2}$ & Kalsium klorida \\
\hline $\mathrm{Ca}^{2+}+\mathrm{SO}_{4}^{2-}$ & $\mathrm{CaSO}_{4}$ & Kalsium sulfat \\
\hline $\mathrm{Ca}^{2+}+\mathrm{NO}_{3}^{-}$ & $\mathrm{Ca}\left(\mathrm{NO}_{3}\right)_{2}$ & Kalsium nitrat \\
\hline $\mathrm{Mg}^{2+}+\mathrm{Cl}^{-}$ & $\mathrm{MgCl}_{2}$ & Magnesium klorida \\
\hline $\mathrm{Mg}^{2+}+\mathrm{SO}_{4}{ }^{2-}$ & $\mathrm{MgSO}_{4}$ & Magnesium sulfat \\
\hline $\mathrm{Mg}^{2+}+\mathrm{NO}_{3}^{-}$ & $\mathrm{Mg}\left(\mathrm{NO}_{3}\right)_{2}$ & Magnesium nitrat \\
\hline $\mathrm{Na}^{+}+\mathrm{Cl}^{-}$ & $\mathrm{NaCl}$ & Natrium klorida \\
\hline $\mathrm{Na}^{+}+\mathrm{SO}_{4}^{2-}$ & $\mathrm{Na}_{2} \mathrm{SO}_{4}$ & Natrium sulfat \\
\hline $\mathrm{Na}^{+}+\mathrm{NO}_{3}^{-}$ & $\mathrm{NaNO}_{3}$ & Natrium nitrat \\
\hline $\mathrm{K}^{+}+\mathrm{Cl}^{-}$ & $\mathrm{KCl}$ & Kalium klorida \\
\hline $\mathrm{K}^{+}+\mathrm{SO}_{4}{ }^{2-}$ & $\mathrm{K}_{2} \mathrm{SO}_{4}$ & Kalium sulfat \\
\hline $\mathrm{K}^{+}+\mathrm{NO}_{3}$ & $\mathrm{KNO}_{3}$ & Kalium nitrat \\
\hline $\mathrm{NH}_{4}^{+}+\mathrm{Cl}^{-}$ & $\mathrm{NH}_{4} \mathrm{Cl}$ & Ammonium klorida \\
\hline $\mathrm{NH}_{4}^{+}+\mathrm{SO}_{4}{ }^{2-}$ & $\left(\mathrm{NH}_{4}\right)_{2} \mathrm{SO}_{4}$ & Ammonium sulfat \\
\hline $\mathrm{NH}_{4}^{+}+\mathrm{NO}_{3}^{-}$ & $\mathrm{NH}_{4} \mathrm{NO}_{3}$ & Ammonium nitrat \\
\hline
\end{tabular}

Dari hasil analisis pengaruh antara daya hantar listrik terhadap elektrolit yang terkandung pada air hujan di kota Palu menunjukkan bahwa zatzat elektrolit yang terkandung pada air hujan di kota Palu memiliki kategori ionisasi sempurna (asam kuat, basa kuat dan garam netral dari asam kuat serta basa kuat yang memiliki daya hantar listrik baik) dan ionisasi sebagian (asam lemah, basa lemah dan zat-zat yang mengalami ionisasi parsial sehingga memiliki nilai daya hantar listrik yang kurang baik). Analisis korelasi antar ion-ion berada di rentang nilai $0.186-0.878$.

Hasil analisis korelasi antara kesadahan air total (KT) terhadap ion-ion menunjukkan bahwa air hujan pada Stasiun Meteorologi Mutiara Palu memiliki korelasi yang cukup tinggi yakni berada di rentang $0.212-0.995$. Korelasi tertinggi yaitu antara kesadahan air total terhadap $\mathrm{Ca}^{+}$dengan nilai $0.995, \mathrm{Mg}^{2+}$ dengan nilai 0.587 dan terhadap $\mathrm{Na}^{+}$dengan nilai korelasi 0.520 . Artinya bahwa air hujan tersebut terkontaminasi dengan unsur kation yang banyak di jumpai pada air laut. Hasil penelitian ini didukung oleh[191,[20] yang menyebutkan bahwa kesadahan pada prinsipnya adalah terkontaminasi air dengan unsur kation seperti $\mathrm{Na}$, Ca dan $\mathrm{Mg}$ yang paling banyak di jumpai pada air laut. Korelasi berdasarkan reaksi kimia yang mungkin terjadi untuk $\mathrm{CaCl}_{2}$ sebesar 0.213 , $\mathrm{CaSO}_{4}$ sebesar 0.186, $\mathrm{Ca}\left(\mathrm{NO}_{3}\right)_{2}$ sebesar 0.303 , $\mathrm{MgCl}_{2}$ sebesar 0.299, $\mathrm{MgSO}_{4}$ sebesat 0.327, $\mathrm{Mg}\left(\mathrm{NO}_{3}\right)_{2}$ sebesar 0.297, $\mathrm{NaCl}$ sebesar 0.412, $\mathrm{Na}_{2} \mathrm{SO}_{4}$ sebesar $0.418, \mathrm{NaNO}_{3}$ sebesar $0.270, \mathrm{KCl}$ sebesar 0,556, $\mathrm{K}_{2} \mathrm{SO}_{4}$ sebesar $0.596, \mathrm{KNO}_{3}$ sebesar $0.354, \mathrm{NH}_{4} \mathrm{Cl}$ sebesar 0.494, $\left(\mathrm{NH}_{4}\right)_{2} \mathrm{SO}_{4}$ sebesar 0.618 , dan $\mathrm{NH}_{4} \mathrm{NO}_{3}$ sebesar 0.444 . 
Tabel 4. Analisis korelasi antar senyawa kimia pada air hujan

\begin{tabular}{|c|c|c|c|c|c|c|c|c|c|}
\hline & DHL (mho/cm) & $\begin{array}{c}\mathrm{Ca}^{2+} \\
(\mathrm{mg} / \mathrm{L}) \\
\end{array}$ & $\begin{array}{c}\mathrm{Mg}^{2+} \\
(\mathrm{mg} / \mathrm{L}) \\
\end{array}$ & $\begin{array}{c}\mathrm{Na}^{+} \\
(\mathrm{mg} / \mathrm{L})\end{array}$ & $\begin{array}{c}\mathrm{K}^{+} \\
(\mathrm{mg} / \mathrm{L})\end{array}$ & $\begin{array}{c}\mathrm{NH}_{4}{ }^{+} \\
(\mathrm{mg} / \mathrm{L})\end{array}$ & $\begin{array}{c}\mathrm{Cl}^{-} \\
(\mathrm{mg} / \mathrm{L})\end{array}$ & $\begin{array}{c}\mathrm{SO}_{4}{ }^{2-} \\
(\mathrm{mg} / \mathrm{L})\end{array}$ & $\begin{array}{c}\mathrm{NO}_{3}^{-} \\
(\mathrm{mg} / \mathrm{L})\end{array}$ \\
\hline \multicolumn{10}{|l|}{ DHL } \\
\hline \multicolumn{10}{|l|}{$p$-value } \\
\hline $\mathrm{Ca}^{2+}$ & 0.303 & & & & & & & & \\
\hline$p$-value & 0.000 & & & & & & & & \\
\hline $\mathrm{Mg}^{2+}$ & 0.499 & 0.521 & & & & & & & \\
\hline$p$-value & 0.000 & 0.000 & & & & & & & \\
\hline $\mathrm{Na}^{+}$ & 0.533 & 0.463 & 0.791 & & & & & & \\
\hline$p$-value & 0.000 & 0.000 & 0.000 & & & & & & \\
\hline $\mathrm{K}^{+}$ & 0.799 & 0.375 & 0.601 & 0.612 & & & & & \\
\hline$p$-value & 0.000 & 0.000 & 0.000 & 0.000 & & & & & \\
\hline $\mathrm{NH}_{4}{ }^{+}$ & 0.791 & 0.379 & 0.580 & 0.615 & 0.872 & & & & \\
\hline$p$-value & 0.000 & 0.000 & 0.000 & 0.000 & 0.000 & & & & \\
\hline $\mathrm{Cl}^{-}$ & 0.643 & 0.213 & 0.299 & 0.412 & 0.556 & 0.494 & & & \\
\hline$p$-value & 0.000 & 0.000 & 0.000 & 0.000 & 0.000 & 0.000 & & & \\
\hline $\mathrm{SO}_{4}{ }^{2-}$ & 0.807 & 0.186 & 0.327 & 0.418 & 0.596 & 0.618 & 0.878 & & \\
\hline$p$-value & 0.000 & 0.002 & 0.000 & 0.000 & 0.000 & 0.000 & 0.000 & & \\
\hline $\mathrm{NO}_{3}{ }^{-}$ & 0.673 & 0.303 & 0.297 & 0.270 & 0.354 & 0.444 & 0.453 & 0.591 & \\
\hline$p$-value & 0.000 & 0.000 & 0.000 & 0.000 & 0.000 & 0.000 & 0.000 & 0.000 & \\
\hline $\mathrm{KT}$ & 0.340 & 0.995 & 0.587 & 0.520 & 0.417 & 0.420 & 0.235 & 0.212 & 0.318 \\
\hline$p$-value & 0.000 & 0.000 & 0.000 & 0.000 & 0.000 & 0.000 & 0.000 & 0.000 & 0.000 \\
\hline
\end{tabular}

\section{Kesimpulan}

Kualitas air hujan di Kota Palu dominan berada pada kategori hujan asam. Unsur kimia yang terkandung pada air hujan tersebut merupakan senyawa anorganik yang berasal dari alam berbentuk mineral. Hasil reaksi kimia menunjukkan bahwa kandungan mineral yang terdapat di dalam air hujan adalah mineral dari lautan berupa larutan garam. Penyebaran DHL terhadap $\mathrm{pH}$ terbanyak berada pada saat nilai $\mathrm{pH}<6$. Kondisi yang telah di jelaskan dapat dijadikan sebagai informasi dan acuan terhadap potensi hujan dengan kategori asam atau basa yang sewaktu-waktu dapat terjadi pada periode mendatang.

\section{Daftar Pustaka}

1. Matahelumual, B. C., Potensi terjadinya hujan asam di Kota Bandung. J. Lingkung. dan Bencana Geol., 1(2): 59-70 (2016).

2. Alfiandy, S., Hutauruk, R. C. H. \& Permana, D. S., Peran dinamika laut dan topografi terhadap pola hujan tipe lokal di wilayah Kota Palu. DEPIK J. Ilmu-Ilmu Perairan, Pesisir dan Perikan., 9(2): 173-183 (2020).

3. Alfiandy, S., Permana, D. S., Nurjaman, A. W., Kurnia, W. G., Prastika, L., Panggabean, H., Rahman, M. S. D. P., et al., Analisis Iklim Provinsi Sulawesi Tengah berdasarkan Data Pemantau Cuaca Otomatis BMKG. Bul. GAW Bariri, 1(1): 1-11 (2020).

4. Satriawan, D., Cilacap, P. N., Soetomo, J., Sidakaya, N. \& Tlp, C., Analisis kuantitatif acidity level sebagai indikator kualitas air hujan di Kabupaten Cilacap. J. Rekayasa Sist. Ind., 3(2): 112-116 (2018). 
5. Kulp, J. L., Acid Rain: Causes, effects, and control. Regulation, (1990).

6. Silalahi, H. N., Manaf, M. \& Alianto, A., Water Quality Of Maruni Beach Manokwari Regency. J. Sumberd. Akuatik Indopasifik, 1(1): 33-42 (2017).

7. Paweka, Y. M., Analisis Natrium dalam Air Laut di Sekitar Pesisir Pantai Papua dengan Metode Spektroskopi Serapan Atom. Indones. J. Appl. Sci., 7(2): 19-24 (2017).

8. Apriyanti, E., Analisis tingkat keasaman $(\mathrm{pH})$ air hujan di Kota Makassar. J. Ilm. Pena Sains dan Ilmu Pendidik., 7(1): 42-50 (2017).

9. Alfiandy, S., Virgianto, R. H. \& Putri, A. S., Modeling of daily PM 2.5 concentration based on the principal components regression in South and Central Jakarta. in Journal of Physics: Conference Series, 1434(1): 012012 (2020).

10. Kurniawan, A., Pembuatan model sederhana pengaruh gas $\mathrm{CO} 2, \mathrm{SO} 2$ dan $\mathrm{NO} 2$ terhadap tingkat keasaman air hujan. J. Meteorol. dan Geofis., 12(1): (2011).

11. Kusuma Wardhani, N. \& Ihwan, A., Studi Tingkat Keasaman Air Hujan Berdasarkan Kandungan Gas CO2, SO2 Dan NO2 Di Udara (Studi Kasus Balai Pengamatan Dirgantara Pontianak). Prism. Fis., 3(1): 914 (2015).

12. Achmad, R., Kimia lingkungan. Andi Offset, (2004).

13. Sudalma, S., Purwanto, P. \& Santoso, L. W., Model sebaran SO42- dan NO3- dalam air hujan di Kota Semarang. Universitas Diponegoro, (2015).

14. Budiwati, T., Budiyono, A., Setyawati, W. \& Indrawati, A., Analisis Korelasi Pearson untuk Unsur-Unsur Kimia Air Hujan Di Bandung. J. Sains Dirgant., 7(2): 100-112 (2010).

15. Mustofa., Modul Perkuliahan Meteorologi dan Klimatologi. Sekolah Tinggi Keguruan dan Ilmu Pendidikan Persatuan Guru Republik Indonesia (STKIP PGRI) Pontianak, (2011).

16. Pohan, N., Pencemaran Udara dan Hujan Asam. Universitas Sumatera Utara, (2002).

17. Katulistiyani, R., Ihwan, A. \& Nurhasanah., Analisis terjadinya hujan asam di Kota Pontianak akibat emisi gas dari industri dan kendaraan. Prism. Fis., 3(1): 15-20 (2015).

18. Irwan, F. \& Afdal, A., Analisis Hubungan Konduktivitas Listrik Dengan Total Dissolved Solid (TDS) Dan Temperatur Pada Beberapa Jenis Air. J. Fis. Unand, 5(1): 85-93 (2016).

19. Astuti, D. W., Fatimah, S. \& Anie, S., Analisis Kadar Kesadahan Total Pada Air Sumur Di Padukuhan Bandung Playen Gunung Kidul Yogyakarta. J. Anal. Environ. Chem., 1(1): 69-73 (2016).

20. Rosvita, V., Fanani, Z. \& Pambudi, I. A., Analisa Kesadahan Total (CaCO3) Secara Kompleksometri Dalam Air Sumur Di Desa Clering Kabupaten Jepara. Indones. J. Farm., 4(1): 16-20 (2019). 